\title{
The Sensitivity of Gram-negative Bacteria, Recovered from Aerosols, to Lysozyme and Other Hydrolytic Enzymes
}

\author{
By P. HAMBLETON \\ Microbiological Research Establishment, Porton Down, \\ Salisbury, Wiltshire
}

(Accepted for publication I4 January 1970)

SUMMARY

The susceptibility of five strains of bacteria, recovered after storage in the aerosol state, to certain hydrolytic enzymes has been examined. Aerosolized Escherichia coli organisms, strains B and JEPP, rapidly became susceptible to the bactericidal effects of lysozyme, ribonuclease, deoxyribonuclease and trypsin. E. coli strain coMmUNE and Serratia marcescens strain 8 UK organisms remained insensitive to all four enzymes, Aerobacter aerogenes strain $\mathbf{H}$ organisms developed sensitivity to lysozyme only. Raffinose, dextran, glucose, glycerol or sodium glutamate added to the bacterial suspensions increased their survival time as aerosols and decreased the sensitivity of survivors to lysozyme. These results support the hypothesis that changes in the outer wall structure of bacteria precede, and possibly contribute to, the death of organisms in the aerosol state.

\section{INTRODUCTION}

Bacterial survival in aerosols depends on a number of factors including relative humidity, composition of the gaseous environment and the compositions of both spray and collecting fluids (Webb, I960; Cox, 1966a, $b$; Benbough, 1967; Cox \& Baldwin, 1967). Comparatively little is known about the effect of aerosolization upon the integrity of bacterial walls and membranes.

The Gram-negative bacterial wall comprises an inner rigid layer of mucopolysaccharide, which can be depolymerized by lysozyme, and a more flexible lipoproteinlipopolysaccharide component (Salton, I957; Weidel, Frank \& Martin, 1960) which overlays the mucopolysaccharide and protects it from the action of lysozyme, possibly by impeding penetration of the enzyme into the wall. Salton (1957) and Noller \& Hartsell (196I) showed that Gram-negative bacteria can be made sensitive to lysozyme by certain pretreatments which appear to act by disrupting the outer wall complex (Voss, 1967; Wilkinson, 1968). It seemed possible, therefore, that changes in the structure of the bacterial wall, following aerosolization, might be detected by the development of sensitivity to various hydrolytic enzymes. Some indication of such a change has been observed by Maltman (1969), who studied the effects of lysozyme, ribonuclease and deoxyribonuclease on Klebsiella pneumoniae organisms that had been recovered from aerosols.

A number of substances improve the survival of bacteria in an aerosol and it has been suggested that these act by either limiting water loss from the organism (Cox, I $966 a$ ), replacing structural water (Webb, I960) or through interaction with specific 
intracellular sites (Benbough, 1969). The work described here was designed to test the propositions that damage to the bacterial wall preceded, and possibly contributed to, the death of bacteria atomized from aqueous suspension, and that certain 'protecting' agents acted by preventing these changes in structure.

\section{METHODS}

Organisms and growth conditions. Stock cultures of Escherichia coli (strains B, JEPP and COMMUNE), Aerobacter aerogenes (strain H) and Serratia marcescens (strain 8UK) were maintained as frozen pellets at $-70^{\circ}$ (Cox, 1968). For use, the pellets were thawed, streaked on tryptone agar plates (Cox, 1966a) and cultures grown from individual colonies. For each experiment, cultures of $E$. coli (strains B, JEPP and COMMUNE) and $A$. aerogenes $\mathrm{H}$ were grown in shaken conical flasks $(750 \mathrm{ml}$.) containing $30 \mathrm{ml}$. of the chemically defined medium of Benbough (1967) for $16 \mathrm{hr}$ at $37^{\circ}$; S. marcescens 8UK was grown in the same way, but at $28^{\circ}$.

Preparation of suspensions for spraying. Cultures were harvested by centrifuging in an MSE bench centrifuge ( $3000 \mathrm{~g}$, $10 \mathrm{~min}$.), washed twice with distilled water and finally resuspended in distilled water to about $10^{10}$ organisms $/ \mathrm{ml}$. Protecting agents were added immediately before aerosol generation. The substances used, and final concentrations were: raffinose $(0.3 \mathrm{M})$, glucose $(0.3 \mathrm{M})$, glycerol $(0.3 \mathrm{M})$, dextran (mol. wt I I $5,000,5 \% \mathrm{w} / \mathrm{v})$ and sodium glutamate $(0 \cdot \mathrm{I} 3 \mathrm{M})$.

Generation and collection of aerosols. Aerosols were generated using a I- or 3-jet Collison spray (Green \& Lane, 1957), mixed with a secondary air supply of controlled relative humidity $(\mathrm{RH})$ and stored in a 751 . rotating drum (Goldberg, Watkins, Boerke \& Chatigny, 1958). Aerosol samples were collected by raised impingers (May \& Harper, I957) containing I M-sucrose in 20 mM-potassium phosphate buffer (Cox, I966a). The sucrose in the collecting fluid minimized loss of viability of bacteria on rehydration without affecting enzyme activity.

The survival of bacteria in aerosols. Viability of aerosolized bacteria was estimated as described by Cox (1966a).

The sensitivity of aerosolised bacteria to enzymes. $2 \cdot 0 \mathrm{ml}$. of a suspension (10 ${ }^{8}$ organisms $/ \mathrm{ml}$.) of bacteria recovered from aerosols, or diluted suspension which had not been aerosolized, were added to $\mathrm{I} \cdot 0 \mathrm{ml}$. phosphate buffer containing lysozyme, ribonuclease, deoxyribonuclease or trypsin, $10 \mu \mathrm{g} . / \mathrm{ml}$. (The enzymes were obtained from B.D.H. Chemicals Ltd., Poole, Dorset, England.) The suspensions were then incubated for $\mathrm{I} \mathrm{hr}$ at $37^{\circ}$. Controls contained no added enzyme.

Estimation of survivors. Suspensions were diluted in phosphate buffer containing sucrose $(0.3 \mathrm{M})$ and the numbers of colony-forming units from known volumes on tryptone agar plates were counted. Survivors were estimated before and after incubation with enzymes.

\section{RESULTS}

The sensitivity of bacteria recovered from aerosols to some enzymes

Prior to aerosolization, washed suspensions of Escherichia coli (strains B, JEPP and COMMUNE), Serratia marcescens 8UK and Aerobacter aerogenes $\mathrm{H}$ were all resistant to the bactericidal effects of lysozyme, ribonuclease, deoxyribonuclease and trypsin. Even after incubation with each of the enzymes for $\mathrm{I} \mathrm{hr}$ at $37^{\circ}$ the maximum decrease 
in viability of each suspension was less than $2 \%$. Fig. I $a$ shows that viability of $E$. coli B organisms stored in aerosols decreased from about $85 \%$ after I sec. storage to I $4 \%$ after $10 \mathrm{~min}$. and $6 \%$ after $30 \mathrm{~min}$. The effect of enzymes upon the viability of E. coli в organisms recovered from aerosols is shown in Fig. I $b$. Lysozyme consistently

(a)

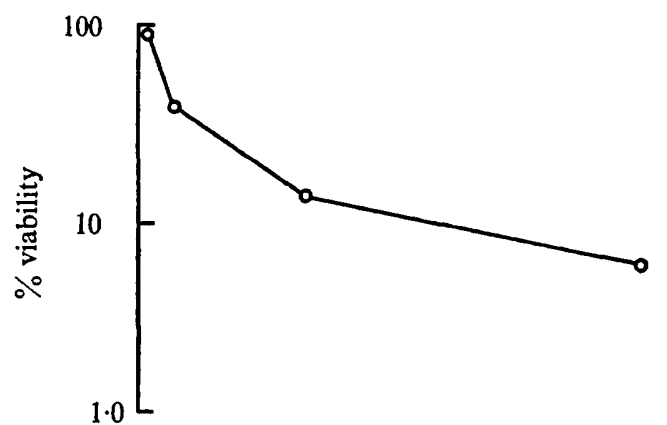

(b)

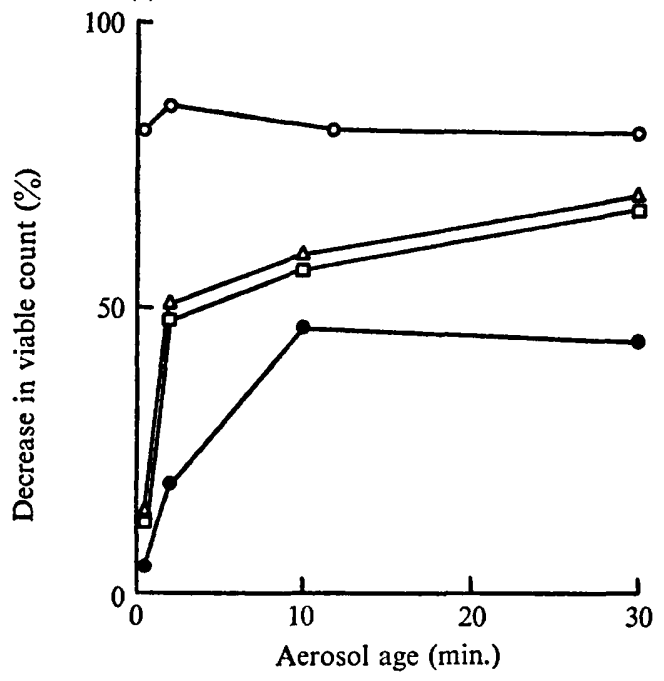

Fig. I (a)

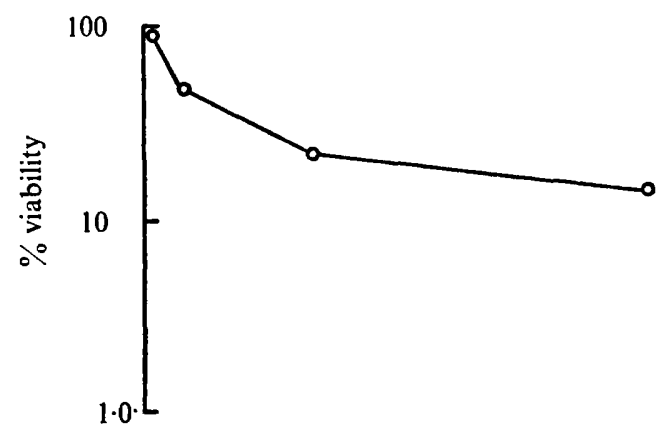

(b)

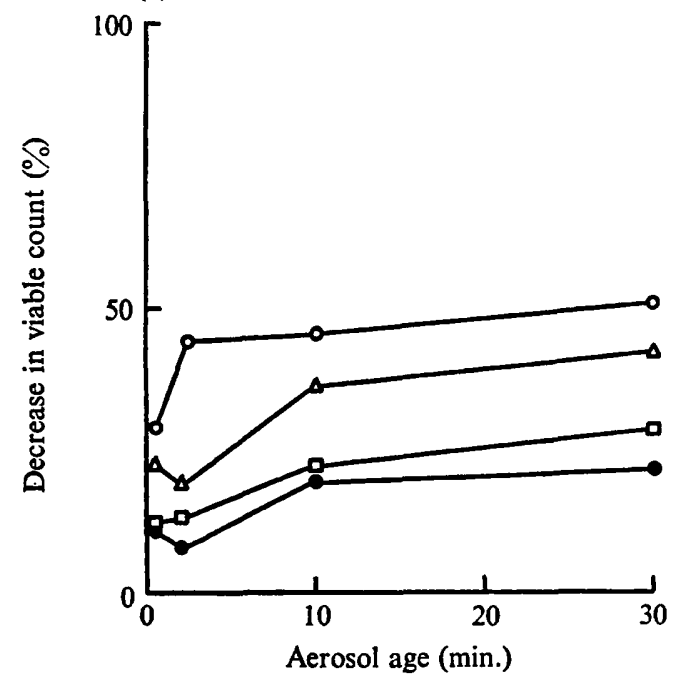

Fig. 2

Fig. I (a). The death rate of $E$. coli B sprayed from distilled water into air at $75 \% \mathrm{RH}$.

Fig. I $(b)$. The effect of some enzymes on the viability of $E$. coli B recovered after spraying into air at $75 \%$ RH. Organisms were incubated with each enzyme (10 $\mu \mathrm{g} . / \mathrm{ml}$.) for $\mathrm{I} \mathrm{hr}$ at $37^{\circ}$. $O$, Lysozyme; $\triangle$, ribonuclease; $\square$, deoxyribonuclease; $\boldsymbol{O}$, trypsin.

Fig. 2(a). The death rate of $E$. coli JEPP sprayed from distilled water into air at $75 \% \mathrm{RH}$.

Fig. $2(b)$. The effect of some enzymes on the viability of $E$. coli JEPP recovered after spraying into air at $75 \% \mathrm{RH}$. Organisms were incubated with each enzyme (10 $\mu \mathrm{g}$. $/ \mathrm{ml}$.) for $\mathrm{I} \mathrm{hr}$ at $37^{\circ}$. $O$, lysozyme; $\triangle$, ribonuclease; $\square$, deoxyribonuclease; $\bullet$, trypsin.

decreased the viable population by about $80 \%$, this value being independent of aerosol age. The decreases in viable counts following treatment with ribonuclease, dexoyribonuclease and trypsin were less marked with organisms from aerosols aged I sec. but the lethal effect of these enzymes became marked when bacteria were kept in the aerosol state for longer periods. 
With $E$. coli JEPP organisms the effects of enzymes were less marked than with suspensions of $E$. coli B. Fig. $2 a$ shows that survival of $E$. coli JEPP was nearly $100 \%$ after I sec. in aerosols ( $95 \%$ viability) but decreased subsequently ( $16 \%$ viability after $30 \mathrm{~min}$.). The increased susceptibility of aerosolized $E$. coli JEPP organisms to treatment with enzymes is shown in Fig. $2 b$. Lysozyme decreased the viability of organisms collected from aerosols by about $50 \%$. The other enzymes were always less effective than lysozyme but still showed marked effects on the viability of recovered bacteria.

(a)

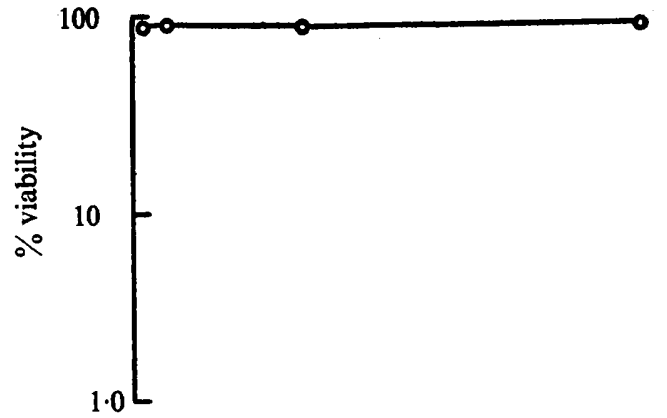

(b)

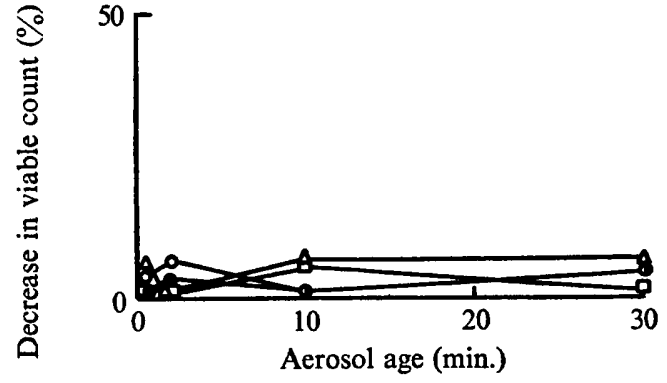

Fig. 3 (a)

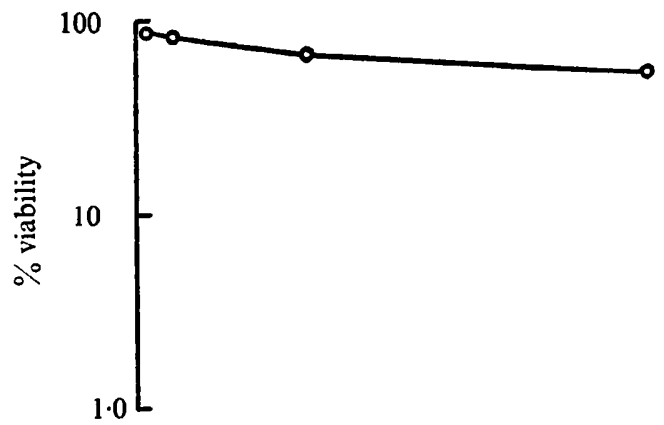

(b)

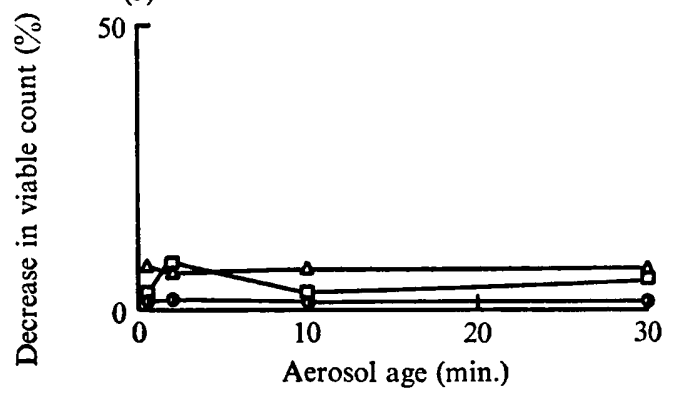

Fig. 4

Fig. 3(a). The death rate of E. coli commune sprayed from distilled water into air at $75 \% \mathrm{RH}$.

Fig. $3(b)$. The effect of some enzymes on the viability of $E$. coli communE recovered after spraying into air at $75 \% \mathrm{RH}$. Organisms were incubated with each enzyme (Io $\mu \mathrm{g}$./ $/ \mathrm{ml}$.) for $\mathrm{I} \mathrm{hr}$ at $37^{\circ} . \bigcirc$, lysozyme; $\triangle$, ribonuclease; $\square$, deoxyribonuclease; $\bullet$, trypsin.

Fig. $4(a)$. The death rate of $S$. marcescens $8 \mathrm{UK}$ sprayed from distilled water into air at $75 \%$ RH.

Fig. $4(b)$. The effect of some enzymes on the viability of $S$. marcescens $8 \mathrm{UK}$ recovered after spraying into air at $75 \% \mathrm{RH}$. Organisms were incubated with each enzyme (Io $\mu \mathrm{g} . / \mathrm{ml}$.) for I hr at $37^{\circ}$. O, Lysozyme; $\triangle$, ribonuclease; $\square$, deoxyribonuclease; $\boldsymbol{\bullet}$, trypsin.

Escherichia coli COMMUNE organisms, unlike strains B and JEPP, survived well in the aerosol state (Fig. 3a), viability was $90 \%$ after storage for $30 \mathrm{~min}$. The organisms recovered from aerosols were resistant to enzymes (Fig. $3 b$ ) and the decreases in the numbers of viable organisms, following various enzyme treatments, never exceeded $8 \%$.

With Escherichia coli (strains B, JEPP and COMMUNE) there was a correlation between the survival of organisms in the aerosol state and their subsequent resistance to the lethal action of some enzymes. This relationship was also evident with Serratia mar- 
cescens 8uK bacteria which survived well in aerosols (Fig. $4 a$ ) and when recovered from the aerosol state were resistant to the bactericidal effect of lysozyme, ribonuclease, deoxyribonuclease and trypsin.

Aerobacter aerogenes $\mathrm{H}$ organisms had survival characteristics that closely resembled those of Serratia marcescens 8UK (Fig. $5 a$ ). Fig. $5 b$ shows that $A$. aerogenes bacteria

(a)

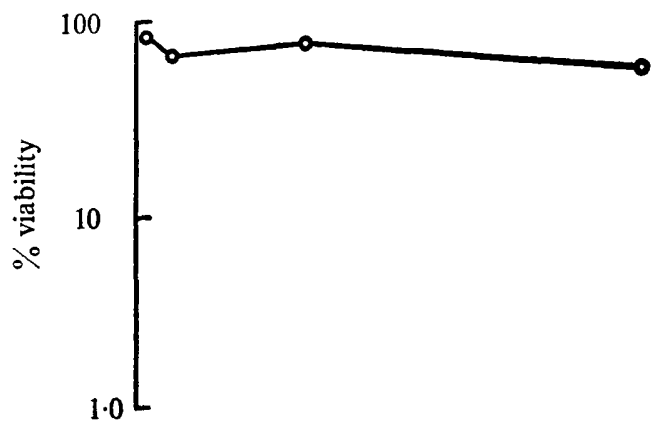

(b)

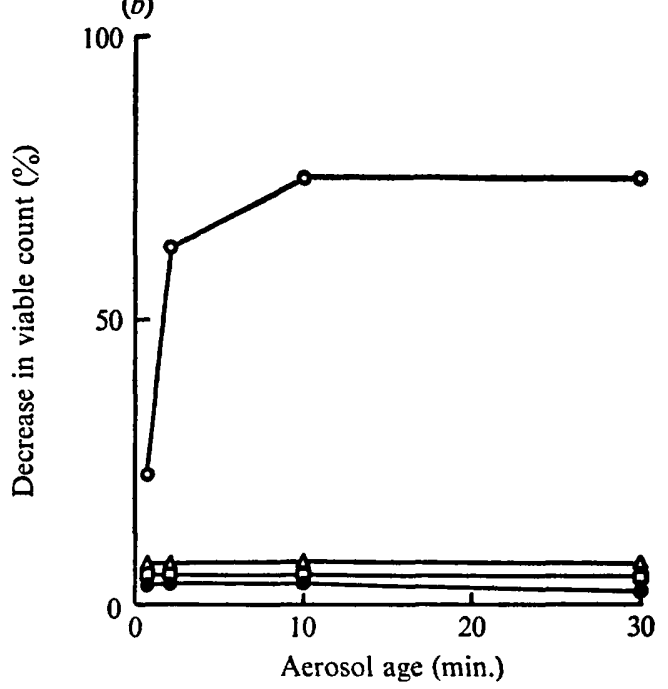

Fig. 5(a). The death rate of $A$. aerogenes $\mathrm{H}$ sprayed from distilled water into air at $75 \% \mathrm{RH}$.

Fig. $5(b)$. The effect of some enzymes in the viability of $A$. aerogenes $\mathrm{H}$ recovered after spraying into air at $75 \%$ RH. Organisms were incubated with each enzyme (10 $\mu \mathrm{g} . / \mathrm{ml}$.) for $\mathrm{I} \mathrm{hr}$ at $37^{\circ}$. $\bigcirc$, Lysozyme; $\triangle$, ribonuclease; $\square$, deoxyribonuclease; $\bullet$, trypsin.

collected from areosols were unaffected by ribonuclease, deoxyribonuclease and trypsin. However, the viable count of organisms after I sec. in aerosols was decreased by about $20 \%$ by lysozyme treatment and this susceptibility increased as the age of aerosols increased.

The effect of composition of the spray fluid on the sensitivity of bacteria recovered from aerosols to some enzymes

Suspensions of Escherichia coli strain B were sprayed from solutions containing raffinose $(0.3 \mathrm{M})$, dextran $(5 \%, \mathrm{w} / \mathrm{v})$, glucose $(0.3 \mathrm{M})$, glycerol $(0.3 \mathrm{M})$ or sodium 
glutamate $(0.13 \mathrm{M})$ and the sensitivities of surviving organisms to some enzymes were examined (Table I). Clearly, all the additives lowered the sensitivity of bacteria recovered from aerosol to lysozyme; raffinose (which was present in the greatest mass concentration) and dextran were the most effective substances tested. Similarly, organisms sprayed from solutions containing these protecting agents and recovered were less susceptible to ribonuclease and deoxyribonuclease. Glucose, glycerol, sodium glutamate and dextran were less effective than raffinose in decreasing the susceptibility of recovered bacteria to trypsin.

The protecting agents did not act simply by inactivating the enzymes since the sensitivities of bacteria aerosolized from water to enzyme treatments were not affected by the addition of these protective substances to the collecting fluid.

Table I. The effect of composition of spray fluid on the sensitivity to some enzymes of Escherichia coli B collected after storage in aerosols at $75 \% \mathrm{RH}$ for $10 \mathrm{~min}$.

Escherichia coli в organisms were aerosolized from various spray fluids into air at $75 \%$ RH. Samples were collected after storage in aerosols for $10 \mathrm{~min}$. and incubated with each of the enzymes (I0 $\mu \mathrm{g}$. $/ \mathrm{ml}$.) for I hr. at $37^{\circ}$. Numbers of viable organisms were estimated before and after incubation with the enzymes.

\begin{tabular}{|c|c|c|c|c|}
\hline \multirow[b]{2}{*}{ Spray fluid } & \multicolumn{4}{|c|}{ Decrease in viable count $(\%)$} \\
\hline & Lysozyme & $\begin{array}{c}\text { Ribo- } \\
\text { nuclease }\end{array}$ & $\begin{array}{c}\text { Deoxyribo- } \\
\text { nuclease }\end{array}$ & Trypsin \\
\hline Distilled water & $8 I$ & $6 I$ & 55 & 52 \\
\hline Raffinose $(0.3 \mathrm{M})$ & 8 & 7 & 7 & 14 \\
\hline Dextran $(5 \%, w / v)$ & 7 & 4 & 0 & 40 \\
\hline Glucose $(0.3 \mathrm{M})$ & 21 & 0 & 2 & 57 \\
\hline Glycerol (0.3 M) & 32 & 0 & 0 & 43 \\
\hline Sodium glutamate $(0.13 \mathrm{M})$ & 22 & 9 & 7 & 48 \\
\hline
\end{tabular}

\section{DISCUSSION}

Although the walls of Gram-negative bacteria contain mucopeptide, generally these organisms are resistant to lysozyme. This probably is due to the lipoproteinlipopolysaccharide outer wall layer which prevents access of the enzyme to the mucopeptide (inner wall) substrate. Sensitivity of Gram-negative bacteria to lysozyme can be induced by a variety of pretreatments which apparently alter the bacterial surface, exposing the lysozyme substrate (Salton, 1957; Voss, 1967; Wilkinson, 1968; Work, 1967). Thus, the development of sensitivity to lysozyme of organisms may be used as an indicator of disruption of the outer layers of the bacterial wall. This study shows that changes in the structure of some Gram-negative bacterial envelopes, manifested as the susceptibility of organisms to some enzymes, occurred following aerosolization of bacteria in air at $75 \% \mathrm{RH}$. The viabilities of Escherichia coli strains B and JEPP organisms recovered from aerosols were significantly decreased by lysozyme, ribonuclease, deoxyribonuclease and trypsin.

The viabilities of organisms of all the bacterial strains examined were, following recovery after $I \mathrm{sec}$. in the aerosol state, invariably greater than $85 \%$. There were significant differences in the sensitivities to enzymes of organisms recovered from aerosols within $2 \mathrm{~min}$. of spraying. This sensitivity correlated with the subsequent survival patterns of bacteria in aerosols. For example, E. coli B which did not survive well in aerosols, were susceptible to the bactericidal action of lysozyme, ribonuclease, 
deoxyribonuclease and trypsin on recovery. Escherichia coli JEPP which survived in aerosols better than $E$. coli B was generally more resistant to the lethal effect of the enzymes; $E$. coli commune and Serratia marcescens organisms, which were very stable in aerosols, were not susceptible to any of the enzymes. Since this correlation existed for organisms recovered from aerosols aged less than $2 \mathrm{~min}$. where the number of viable organisms were similar for all the strains of bacteria examined, it is reasonable to suppose that the differences observed in the susceptibility of organisms surviving in aerosols for $30 \mathrm{~min}$. to enzymes were valid, despite the fact that there then were marked differences in the proportions of viable organisms of each strain recovered.

The resistance of aerosolized Aerobacter aerogenes to ribonuclease, deoxyribonuclease and trypsin fitted into the pattern outlined above. However, these organisms became increasingly sensitive to lysozyme with aerosol age. This suggests that, whilst there was some change in structure of the envelope of aerosolized $A$. aerogenes, the changes were not as extensive as those occurring in the wall and membranes of aerosolized organisms of Escherichia coli strains B and JEPP.

The substances used as spray additives differ in their ability to penetrate the bacterial wall (Cox, 1963, 1966a, 1967). Under the conditions employed raffinose and dextran did not penetrate the wall. Glucose entered only very slowly, as did sodium glutamate, which does not permeate the bacterial membrane. Glycerol alone was capable of penetrating the organism rapidly. In the aerosol, these protecting agents form supersaturated solutions around the bacteria (Cox, 1966a) and as such they probably protect the wall from the otherwise damaging effects of aerosolization. All the substances studied protected the airborne bacteria from the lethal effect of extracellular enzymes. These results support the view that effective concentrations of some protective compounds in the spray fluid aid survival of aerosolized bacteria by preventing changes occurring in the bacterial walls and membranes.

The author thanks Mr I. H. Silver and Dr J. E. Benbough for their helpful discussions and Mr E. A. Wilkin for technical assistance.

\section{REFERENCES}

Benbough, J. E. (1967). Death mechanisms in airborne Escherichia coli. Journal of General Microbiology 47,325 .

Benbough, J. E. (1969). Factors affecting the toxicity of oxygen towards airborne coliform bacteria. Journal of General Microbiology 56, 241.

Cox, C. S. (1963). The mode of action of protecting agents. Ist International Symposium on Aerobiology, p. 345. Published by Naval Biological Laboratory, Naval Supply Center, Oakland, California.

Cox, C. S. (1966a). The survival of Escherichia coli sprayed into air and into nitrogen from distilled water and from solutions of protecting agents as a function of relative humidity. Journal of General Microbiology 43, 383.

Cox, C. S. (1966b). The survival of Escherichia coli in nitrogen atmospheres under changing conditions of relative humidity. Journal of General Microbiology 45, 283.

Cox, C. S. (1967). The aerosol survival of Eschericha coli JEPP sprayed from protecting agents into nitrogen atmospheres under changing relative humidity conditions. Journal of General Microbiology 49, 109.

Cox, C. S. (1968). A method for the routine preservation of micro-organisms. Nature, London 220 , II 39.

Cox, C. S. \& BaLdwin, F. (1967). The toxic effect of oxygen upon the aerosol survival of Escherichia coli B. Journal of General Microbiology 49, 15. 
Green, H. L. \& LANe, W. R. (1957). Particulate Clouds: Dusts, Smokes and Mists. London: E. and F. N. Spon Ltd.

Goldberg, L. J., Watkins, H. M. S., Boerke, E. E. \& Chatigny, M. A. (1958). The use of a rotating drum for the study of aerosols over extended periods of time. American Journal of Hygiene 68, 85.

Maltman, J. R. (1969). In La Revue d'Hygiène et de Medecine Sociale (in the Press).

MAY, K. R. \& HARPER, G. J. (1957). The efficiency of various liquid impinger samplers in bacterial aerosols. British Journal of Industrial Medicine 14, 287.

Noller, E. C. \& HARTSELl, S. E. (I96I). Bacteriolysis of Enterobacteriaceae. I. Lysis of four lytic systems utilizing lysozyme. Journal of Bacteriology 8r, 482.

SALton, M. R. J. (1957). The properties of lysozyme and its action on micro-organisms. Bacteriological Reviews 2I, 82.

Voss, J. G. (1967). Effects of organic cations on the Gram-negative cell wall and their bactericidal activity with EDTA and surface active agents. Journal of General Microbiology 48, 391.

WEBB, S. J. (1960). Factors affecting the viability of airborne bacteria. II. The effect of chemical additions on the behaviour of airborne cells. Canadian Journal of Microbiology 6, 7I.

Weidel, W., Frank, H. \& Martin, H. H. (1960). The rigid layer of the cell wall of Escherichia coli strain B. Journal of General Microbiology 22, 158.

Wirkinson, S. G. (I968). Studies on the cell walls of pseudomonas species resistant to EDTA. Journal of General Microbiology 54, 195.

Work, E. (1967). Factors affecting the susceptibility of bacterial cell walls to the action of lysozyme. Proceedings of the Royal Society Series B 167, 446. 